\title{
The Effect of Quantifying Pulmonary Contusion Extent on The Treatment Management of Blunt Chest Trauma in Children
}

\author{
Caner İsbir $^{1}$ (iD , İsa Kıllı ${ }^{1}$ iD , Yüksel Balcı ${ }^{2}$ iD , Hakan Taşkınlar ${ }^{1}$ iD , Ali Naycı' ${ }^{1}$ iD
}

${ }^{1}$ Mersin University Faculty of Medicine, Department of Pediatric Surgery, Mersin, Turkey

${ }^{2}$ Mersin University Faculty of Medicine, Department of Radiology, Mersin, Turkey

\section{Caner ISBIR}

İsa KILLI

Yüksel BALCI

Hakan TAŞKINLAR

Ali NAYCl

\section{Correspondence: Caner İsbir}

Mersin University Faculty of Medicine, Department of Pediatric Surgery, Mersin, Turkey

Phone: +903242410000

E-mail: caner.isbir@gmail.com

\section{ABSTRACT}

Objective: Post-traumatic pulmonary contusion in children is often asymptomatic at diagnosis and has a good prognosis. The aim of this study was to investigate the clinical significance of the extent of post-traumatic pulmonary contusions and evaluate the timing of complications to determine the safe follow-up period in children with lung contusions.

Methods: The study included pediatric patients who presented to the emergency department after blunt chest trauma and had pulmonary contusion detected on chest computed tomography (CT) between January 2017 and January 2020. Based on the percentage of total lung capacity occupied on thorax CT, pulmonary contusions were classified as grade 1: $<19 \%$ (mild), grade 2: 19\%-27\% (moderate) and grade $3: \geq 28 \%$ (severe). The relationship between pulmonary contusion grade and pulmonary functional status; complications and intensive care admission was examined and the mean time to complication development was determined.

Results: The mean extent of pulmonary contusion after trauma was $17.8 \pm 8.6 \%$ (min-max, 5-100\%) and mild (grade 1) contusion was significantly associated with spontaneous breathing $(p=0.009)$. Contusion grade was not associated with the development of atelectasis, pneumonia, pleural effusion, pneumothorax $(p=0.719)$ or intensive care admission $(p=0.176)$. The mean time to detection of complications (atelectasis, pneumonia, pleural effusion, pneumothorax) on chest $X$-ray was $6.33 \pm 3.78$ days (range, 2-9 days).

Conclusion: The results suggest that although no statistically significance between the extent of pulmonary contusion and complications, patients should be hospitalized for at least 48 hours, then followed-up with chest $X$-ray for 1 week due to possible complications after blunt chest trauma in children.

Keywords: Child, blunt chest trauma, pulmonary contusion

\section{Akciğer Kontüzyon Yaygınlığı Ölçümünün Çocuklardaki Künt Toraks Travmalarında Tedavi Yönetimi Üzerine Etkileri}

ÖZET

Amaç: Çocuklarda travma sonrası gelişen akciğer kontüzyonları sıkıkla tanı anında asemptomatik olup, iyi prognoza sahiptir. Çalışmada travma sonrası gelişen akciğer kontüzyonlarının yaygınlı̆ının klinik öneminin sorgulanması ve akciğer kontüzyonlu olgulardaki komplikasyon gelişme zamanları değerlendirilerek güvenli takip yönetiminin belirlenmesi amaçlandı.

Method: 0cak 2017-0cak 2020 tarihleri arasında, acil servise künt toraks travması sonrası toraks bilgisayarlı tomografilerinde akciğer kontüzyonu tespit edilen çccuk hastalar dahil edildi. Hastaların akciğer kontüzyonları, total akciğer kapasitesindeki yayılımına göre, Grade $1<\% 19$ (hafif), $\% 19 \leq$ Grade $2 \leq \% 27$ (orta), $\% 28 \leq$ Grade 3 (şiddetli) olarak 3 skor değerine ayrıldı. Bu skor değerleri ile solunum fonksiyon durumlarının, komplikasyonların, yoğun bakımda yatma durumlarının ilişkisi incelendi ve ortalama komplikasyon gelişme zamanları belirlendi.

Bulgular: Akciğer kontüzyon yaylım oranı ortalama \%17.78 \pm 8.61 (min:\%5, max:\%100) olduğu ve spontan solunum durumu olan hastalar ile akciğer kontüzyonunun hafif olduğu Grade 1 akciğer kontüzyon değerlerinin anlamlı şekilde birlikte olduğu tespit edildi $(\mathrm{p}=0,009)$. Hastaların akciğerlerdeki kontüzyon skor değerleri ile atelektazi, pnömoni, pelvral efüzyon, pnömotoraks komplikasyonlarının gelişme durumları arasında anlamlı bir farklılı̆ın olmadığı tespit edildi $(\mathrm{p}=0.719)$. Yoğun bakımda yatma durumu ile akciğer kontüzyon skor değerleri arasında anlamlı bir farklıı̆ı̆ olmadığı tespit edildi $(p=0.176)$. Ayrıca takipte akciğer grafileri ile tespit edilen atelektazi, pnömoni, plevral efüzyon, pnömotoraks komplikasyonlarının $6.33 \pm 3.78$ (min:2,max:9) günde geliştiği görüldü.

Sonuç: Çalışmada yer alan hastalardaki akciğer kontüzyon yayılımı ile komplikasyonlar arasında anlamlı bir ilişki tespit edilmemek ile birlikte, bu hasta grubunun olası komplikasyonlar göz önüne alınarak travma sonrası en az 48 saat hastanede yatırlarak izlenmesi, sonrasında 1 hafta akciğer grafileri ile takip edilmesi gerektiği düşünülmektedir.

Anahtar Kelimeler: Çocuk, künt toraks travması, akciğer kontüzyonu

$\begin{array}{ll}\text { Received } & : 30 \text { June } 2021 \\ \text { Accepted } & : \text { : } 20 \text { August } 2021\end{array}$


$\mathbf{P}$ ulmonary contusion is frequently observed in children after blunt chest trauma and occurs due to hemorrhage and edema at the alveolar level (1). Injuries affecting the lung parenchyma and mediastinal structures without rib fractures are more common in children due to their less developed connective tissue and the flexibility of their bones, rib cartilage, and mediastinal structures. Therefore, pulmonary contusions are more common in children than in adults, regardless of trauma severity. Extensive lung contusions can cause serious respiratory problems such as dyspnea, tachypnea, hemoptysis, and hypoxia (1-3). In addition, low lung capacity makes children susceptible to hypoxia, which contributes to post-traumatic morbidity and mortality $(4,5)$. For these reasons, the diagnosis and treatment of lung contusions is considered a priority in children who have sustained trauma.

Only severe post-traumatic pulmonary contusion can be detected by chest X-ray. Therefore, the diagnosis of post-traumatic pulmonary contusion is generally made by chest computed tomography (CT), which is a more sensitive imaging method (6). Most post-traumatic lung contusions are asymptomatic and have a good prognosis, resolving spontaneously within 5 to 7 days. However, it has been reported that pneumonia, pneumothorax, hemothorax, and the need for respiratory support may arise during follow-up, particularly with extensive lung contusions (7). Because they are usually asymptomatic at diagnosis and have good prognosis in children, the clinical significance of lung contusions is controversial, especially in cases with limited lung involvement (8). In addition, a review of the literature shows that there is limited information regarding prognostic criteria and the safe followup period in pediatric patients with post-traumatic lung contusion $(9,10)$.

In this study, we examined the relationship between the extent of lung contusion in relation to total lung capacity detected in thorax CT association with intensive care admission, need for respiratory support, Pediatric Trauma Score values, and frequency and timing of complications in children with lung contusion after blunt chest trauma. Our aim was to contribute to conservative treatment protocols by investigating the importance of the extent of post-traumatic lung contusion in pediatric patients and determining a safe follow-up period.

\section{MATERIALS and METHODS}

This retrospective chart review included pediatric patients who presented to the emergency department after blunt chest trauma and had pulmonary contusion detected by chest CT between January 2017 and January 2020 . The study was approved by the local clinical research ethics committee (2020/17). Patient age, gender, trauma etiology, physical examination findings, Glasgow Coma Scale scores, Pediatric Trauma Score, chest X-ray and CT findings, admission to the intensive care unit, and length of hospital stay were determined. Patients were divided into three groups according to pulmonary functional status: group 1, spontaneously breathing patients; group 2, patients who received oxygen by mask or nasal cannula; and group 3, patients who received invasive mechanical ventilation. The patients' lung contusions were assessed by a radiologist using the grading system described by Wagner and Jamieson, in which the extent of contusion is determined from chest $\mathrm{CT}$ images as a percentage of the total lung capacity (11). According to this system, pulmonary contusions were classified as grade 1: less than $19 \%$ (mild), grade 2: $19 \%$ to $27 \%$ (moderate), or grade 3: $28 \%$ or more (severe).

\section{Statistical Analysis}

The distribution of lung contusion grades in the pulmonary functional status groups was analyzed using Spearman correlation test. Chi-square tests were used to analyze the distribution of unilateral or bilateral lung contusions in the pulmonary functional status groups and analyze the relationships between lung contusion grade and Pediatric Trauma Score, complications, and intensive care admission. Mean and standard deviation values were determined for the time to occurrence of complications.

\section{RESULTS}

The study included 52 patients with lung contusion on CT after blunt chest trauma between January 2017 and January 2020. Of the patients, 15 (28\%) were girls and 37 (71\%) were boys. The mean age was $9.32 \pm 4.48$ years (range, 2-17 years). The most common etiology of trauma was pedestrian accidents $(n=18 ; 34.6 \%)$ and the least common was blunt force trauma $(n=2 ; 3.8 \%)$. The mean extent of lung contusion in relation to total lung capacity was $17.78 \pm 8.61 \%$ (range, $5 \%-100 \%$ ). The extent of lung contusion was grade 1 in 35 patients (67.3\%), grade 2 in 6 patients (11.5\%), and grade 3 in 11 patients (21.1\%) (Figure 1-3). Contusions were unilateral in 28 patients (53.8\%) and bilateral in 24 patients (46.2\%). Physical examination at admission revealed dyspnea, tachypnea, and reduced respiratory sounds in 9 patients (17.3\%). Of these patients, 8 also had pneumothorax and 1 had hemopneumothorax. 


\begin{tabular}{|l|l|l|}
\hline $\begin{array}{l}\text { Figure 1: Non-vehicle traffic accident, 13-year- } \\
\text { old male patient, lung contusion spread is 16\% } \\
\text { according to Wagner and Jamieson contusion } \\
\text { classification (Grade 1). }\end{array}$ & $\begin{array}{l}\text { Figure 2: Non-vehicle traffic accident, } \\
\text { 12-year-old female patient, lung contusion } \\
\text { spread is 26\% according to Wagner and } \\
\text { Jamieson contusion classification (Grade 2). }\end{array}$ & $\begin{array}{l}\text { Figure 3: Fall from height, 7-year-old male } \\
\text { patient, 100\% lung contusion spread according } \\
\text { to Wagner and Jamieson contusion classification }\end{array}$ \\
\hline
\end{tabular}

Chest CT demonstrated isolated pulmonary contusion in 39 patients (65.6\%), while 13 patients (34.6\%) also had pneumothorax, hemopneumothorax, rib fracture, and/ or pneumomediastinum. On chest X-rays taken at emergency admission, 4 patients $(7.7 \%)$ had findings suggesting contusion. In addition, 3 patients (5.7\%) with normal chest $\mathrm{X}$-ray at diagnosis exhibited findings consistent with atelectasis limited to the upper or middle lobe of a single lung on chest $X$-rays obtained during the first 72 hours of follow-up. It was determined that 2 of these patients received mechanical ventilation after trauma, while 1 patient received oxygen support via nasal cannula in the intensive care unit. Atelectasis resolved in a mean of $6.44 \pm 1.34$ days (range, 5-8 days) with respiratory physiotherapy.

With conservative treatment, 45 patients (86\%) recovered with no problems, whereas 7 patients who were followed in the intensive care unit developed complications of atelectasis $(n=3)$, pneumonia $(n=1)$, pleural effusion $(n=1)$, and pneumothorax $(n=2)$ at a mean of $6.33 \pm 3.78$ days (range, 2-9 days) in follow-up of patients. The only mortality occurred in one patient with extensive subarachnoid hemorrhage. Evaluation of pathologies detected in addition to chest trauma showed that findings of head trauma were most frequent $(n=9 ; 17.3 \%)$, while 33 patients $(63.5 \%)$ had no trauma findings other than chest trauma.

When grouped according to their respiratory functional status at time of admission, there were 38 patients in group 1 (spontaneously breathing patients), 10 patients in group 2 (patients receiving oxygen via mask or nasal cannula), and 4 patients in group 3 (invasive mechanical ventilation). The patients in group 2 received oxygen via mask or nasal cannula for a mean of $2.2 \pm 2.48$ days (range, 1-9 days) and those in group 3 were intubated for a mean of 7.25 \pm 3.3 days (range, 3-11 days). The relationship between lung contusion extent and pulmonary functional status groups was examined (Table 1). There was a significant association between spontaneous breathing and grade 1 (mild) lung contusion ( $p=0.009$ ) but there was no significant difference in the distribution of lung contusion extent in intubated patients ( $p>0.05$ ). Unilateral or bilateral lung contusions did not differ significantly in terms of pulmonary function $(p=0.522$ ).

Table 1. Distribution of pulmonary functional status according to extent of lung contusion.

\begin{tabular}{|c|c|c|c|c|}
\hline \multirow{2}{*}{$\begin{array}{c}\text { Respiratory Functional } \\
\text { Status }\end{array}$} & \multicolumn{3}{|c|}{ Grade } & \multirow[b]{2}{*}{$\mathrm{p}$} \\
\hline & $\begin{array}{c}\text { Grade 1, } \\
\text { n (\%) }\end{array}$ & $\begin{array}{c}\text { Grade 2, } \\
\text { n (\%) }\end{array}$ & $\begin{array}{c}\text { Grade 3, } \\
\text { n (\%) }\end{array}$ & \\
\hline Spontaneous* & 29 (82.9) & $5(83.3)$ & $4(36.4)$ & \multirow{3}{*}{0.009} \\
\hline Mask high-flow oxygen & $4(11.4)$ & $1(16.7)$ & $5(45.5)$ & \\
\hline Intubated & $2(5.7)$ & $0(0.0)$ & $2(18.2)$ & \\
\hline
\end{tabular}

The patients' mean Glasgow Coma Scale score determined during evaluation in the emergency department was 14.23 \pm 1.64 (range, 6-15), and their mean Pediatric Trauma Score at admission was $9.34 \pm 1.85$ (range, 2-12). Pediatric Trauma Score was not significantly associated with lung contusion grade $(p=0.07)$. No significant differences in the distribution of atelectasis, pneumonia, pelvic effusion, and pneumothorax complications were observed according to lung contusion grade ( $p=0.719$ ) (Table 2$)$.

Table 2. Distribution of complications according to extent of lung contusion in follow-up of patients.

\begin{tabular}{|c|c|c|c|c|}
\hline \multirow[b]{2}{*}{ Complication } & \multicolumn{3}{|c|}{ Grade } & \multirow[b]{2}{*}{$\mathrm{p}$} \\
\hline & $\begin{array}{c}\text { Grade } 1, \mathrm{n} \\
(\%)\end{array}$ & $\begin{array}{c}\text { Grade } 2, \mathrm{n} \\
(\%)\end{array}$ & $\begin{array}{c}\text { Grade } 3, \mathrm{n} \\
(\%)\end{array}$ & \\
\hline Atelectasis & 0 & $1(1.9)$ & $2(3.2)$ & \multirow{5}{*}{0.713} \\
\hline Pneumonia & 0 & 0 & $1(1.9)$ & \\
\hline Pneumothorax & $1(1.9)$ & $1(1.9)$ & 0 & \\
\hline Pleural effusion & $1(1.9)$ & 0 & 0 & \\
\hline None & $33(63.4)$ & $4(7.6)$ & $8(15.3)$ & \\
\hline
\end{tabular}


Thirty-four patients (65.4\%) were followed up only in the ward after diagnosis, while the other 18 patients (34.6\%) were monitored in the intensive care unit. The mean length of hospital stay was 5.68 \pm 4.41 days (range, 2-30 days) in the spontaneous breathing group, $12.60 \pm 5.64$ days (range, 7-23 days) in the oxygen support group, and $25 \pm 7.75$ days (range, 10-45 days) in the invasive mechanical ventilation group. The rate of intensive care admission did not differ significantly according to grade of lung contusion ( $p=0.176$ ) (Table 3 ).

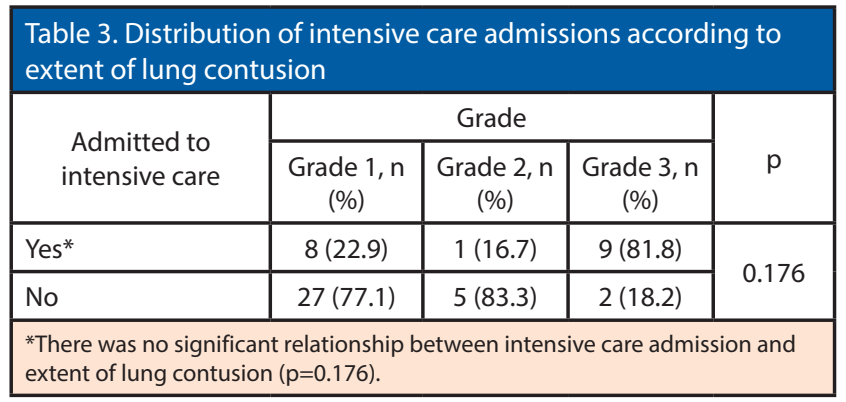

\section{DISCUSSION}

There was no acute distress syndrome or mortality (except one with severe intracranial bleeding) with the wellknown good prognosis of chest blunt trauma in children accoding to the literature in this study $(12,13)$. It was observed that pneumothorax, hemothorax, pneumonia, and pelvic effusion developed as complications after a mean of $6.33 \pm 3.78$ days (range, 2-9 days) of follow-up. There was no significant difference in the distribution of these complications according to the extent of lung contusion $(p=0.719)$. According to these results, unlike adulthood chest traumas, children have better prognosis independent from the extent of pulmonary contusion. However, patients should still be hospitalized for at least the first 48 hours and be followed up with chest X-ray for 1 week due to possible complications.

One of the risk factors associated with poor clinical prognosis in patients with post-traumatic lung contusion is that the contusion is visible on direct X-ray as well as CT $(14,15)$. In this study, only 4 patients had findings consistent with lung contusion on both chest X-ray and $\mathrm{CT}$ at the time of diagnosis. The mean extent of lung contusion in our patients was $17.78 \pm 8.61 \%$, which suggests that pulmonary X-rays are not sensitive enough to detect this degree of contusion. In addition, complications such as atelectasis, pneumothorax, pneumonia, and pleural effusion, which may be associated with lung contusion and are detected by chest X-ray, occurred in 7 (13.5\%) of the patients in this study during follow-up. This shows that even if they lack diagnostic value, chest $X$-rays are a useful examination in the follow-up of this patient group.

Oppenheimer et al. reported that the pathophysiological consequences of lung contusions may result in atelectasis due to loss of perfusion and decreased lung compliance (16). Three (5.7\%) of the patients whose chest X-rays were normal at diagnosis developed lesions consistent with atelectasis on chest X-rays obtained within the first 72 hours. In addition, these patients also required respiratory support starting from admission, despite having initially normal chest radiographs. These results seem to contradict the idea that the visibility of post-traumatic lung contusion on chest $\mathrm{X}$-rays is a strong determinant of clinical severity and prognosis.

Risk factors related to clinical prognosis and pulmonary functional status in patients with post-traumatic lung contusion include bilateral lung contusion and concomitant pneumothorax at diagnosis $(14,15)$. There was no significant relationship between pulmonary contusion in one or both lungs and pulmonary functional status $(p=0.522)$. However, all 9 patients who had dyspnea, tachypnea, and decreased respiratory sounds in clinical evaluation performed at admission had pneumothorax or hemopneumothorax accompanying the lung contusion. On the other hand, Beshay et al. reported in their study of adult chest trauma patients that lung contusion involving more than $50 \%$ of total lung volume was the most important factor increasing the risk of long-term intubation, pneumonia, and ARDS (17). Spontaneous breathing was significantly associated with grade 1 (mild) lung contusion ( $p=0.009)$, while there was no significant difference in the distribution of lung contusion grade in intubated patients $(p>0.05)$. Results of this study supports that children have better prognosis free from the extent of pulmonary contusion then adults.

The Pediatric Trauma Score is a prognostic indicator commonly used in post-trauma evaluation (18). Nair et al. reported that Pediatric Trauma Score may be an indicator for ARDS, which is one consequence of lung contusions (19). In the present study, analysis of the relationship between lung contusion grades and Pediatric Trauma Score values for trauma severity showed that the distribution was homogeneous and there was no significant difference $(p=0.07)$. The fact that the mean extent of lung contusion in our patients was $17.8 \pm 8.6 \%$ should be considered when evaluating this result. 
With advantages such as rapid, high-resolution images and widespread accessibility, CT continues to be the gold standard in the diagnosis of lung contusions after chest trauma (20). Nair et al. emphasized the importance of detecting post-traumatic lung contusions and reported an increased risk of ARDS in severe cases with extensive contusions (19). Raghavendran et al. reported that even patients with lung contusions barely detectable on CT could have oxygenation problems (15). However, regarding to the advantage of computed tomography, Marth et al. reported that in addition to pneumothorax and hemothorax, CT was highly sensitive in the identification of lung contusion and lacerations involving the parenchyma (21). However, they also reported that only $6.5 \%$ of these cases had $\mathrm{CT}$ results that would lead to changes in the trauma treatment regimen (21). CT was preferred as the primary examination used to detect lung contusions due to its diagnostic superiority. There was no significant association between the extent of lung contusion detected on $\mathrm{CT}$ and complications that occurred during clinical follow-up and changed the treatment strategy $(\mathrm{p}=0.719)$. In addition, there was no significant difference in lung contusion grade in the study according to intensive care admission $(p=0.176)$. Taken together, these results show that lung $X$-ray is insufficient in the diagnosis of lung contusion of the mean extent observed in this study, and CT maintains its superiority in determining the treatment strategy at time of diagnosis when additional pathologies such as pneumomediastinum are considered.

In this study, the complications of pneumothorax, pneumonia, pleural effusion, and atelectasis were detected on chest $X$-ray at a mean of $6.33 \pm 3.78$ days (range, 2-9 days) after traumatic lung contusion. Miller et al. suggested that patients with extensive post-traumatic lung contusion usually show clinical deterioration within the first 24 to 48 hours (8). Although the mean extent of post-traumatic lung contusion in the pediatric patients in our study seems safe in terms of complications, we believe that patients should be hospitalized for at least the first 48 hours after trauma and followed up with chest X-ray for 7 days.

This study has some limitations. As it was a retrospective chart review, there is no clinical and radiological data demonstrating the long-term course of lung contusions. The study evaluates the short-term efficacy of prognostic indicators used to determine lung contusion severity. Prospective studies on larger study groups are needed to determine the long-term effects of lung contusions in pediatric patients.

\section{CONCLUSION}

Blunt chest trauma causing pulmonary contusion can be life-threating (15). We belive that, children have better prognosis independent from the extent of pulmonary contusion than adults. However, patients can develop complications detectable by chest X-ray, such as atelectasis, pneumonia, pelvic effusion, and pneumothorax, within $6.33 \pm 3.78$ days (range, 2-9 days) of follow-up. This suggests that these patients should be hospitalized for at least 48 hours and followed with chest X-ray for 1 week after trauma.

\section{REFERENCES}

1) Pearson EG, Fitzgerald CA, Santore MT. Pediatric Thoracic Trauma: Current Trents. Semin Pediatr Surg. 2017; 26: 36-42. DOI:10.1053/j. sempedsurg.2017.01.007

2) Holmes JF, Sokolove PE, Brant WE, et al. A clinical decision rule for identifying children with thoracic injuries after blunt torso trauma. Ann Emerg Med. 2002;39:492-9. DOI:10.1067/mem.2002.122901

3) Allen GS, Cox CS. Pulmonary contusion in children: Diagnosis and management, South Med J. 1998;91:1099-106. DOI:10.1097/00007611-199812000-00002

4) Yanchar NL, Woo K, Brennan M, et al. Chest x-ray as a screening tool for blunt thoracic trauma in children. J Trauma Acute Care Surg. 2013;75:613-9. DOI:10.1097/TA.0b013e31829bb7fe

5) Juan AT. The lung and Pediatric Trauma. Semin PediatrSurg. 2008;17:53-9. DOI:10.1053/j.sempedsurg.2007.10.008

6) Allen GS, Coates NE. Pulmonary contusion: A collective review. Am Surg. 1996;62:895-900.

7) Bakowitz M, Bruns B, McCunn M. Acute lung injury and the acute respiratory distress syndrome in the injured patient. Scand J Trauma Resusc Emerg Med. 2012;20:54. DOI:10.1186/1757-7241-20-54

8) Miller PR, Croce MA, Bee TK, et al. ARDS after pulmonary contusion: accurate measurement of contusion volume Identifies high-risk patients. J Trauma. 2001;51:223-30. DOI:10.1097/00005373-200108000-00003

9) Bliss D, Silen M. Pediatric thoracic trauma. Crit Care Med 2002;30:409-15. DOI: 10.1097/00003246-200211001-00005

10) Nakayama DK, Ramenofsky ML, Rowe MI. Chest injuries in childhood. AnnSurg. 1989;210:770-5.DOI:10.1097/00000658-198912000-00013

11) Wagner RB, Jamieson PM. Pulmonary contusion. Evaluation and classification by computed tomography. Surg Clin North Am. 1989;69:31-40. DOI:10.1016/s0039-6109(16)44732-8

12) Cohn SM. Pulmonary contusion: review of the clinical entity. J Trauma. 1997;42:973-9. DOI:10.1097/00005373-199705000-00033

13) Richardson JD, Adams L, Flint LM. Selective management of flail chest and pulmonary contusion. Ann Surg. 1982;1968:481-7. DOI:10.1097/00000658-198210000-00012

14) Deunk J, Poels TC, Brink M, et al. The clinical outcome of occult pulmonary contusion on multidetector-row computed tomography in blunt trauma patients. J Trauma. 2010;68:387-94. DOI:10.1097/ TA.0b013e3181a7bdbd

15) Raghavendran K, Davidson BA, Helinski JD, et al. A rat model for isolated bilateral lung contusion from blunt chest trauma. Anesth Analg. 2005;101:1482-9. DOI:10.1213/01.ANE.0000180201.25746.1F

16) Oppenheimer L, Craven KD, Forkert L, et al. Pathophysiology of pulmonary contusion in dogs. J Appl Physiol Respir Environ Exerc Physiol. 1979;47:718-28. DOI:10.1152/jappl.1979.47.4.718 
17) Beshay M, Mertzlufft F, Kottkamp HW, et al. Analysis of risk factors in thoracic trauma patients with a comparison of a modern trauma centre: a mono-centre study. World Journal of Emergency Surgery. 2020;15:45. DOI: 10.1186/s13017-020-00324-1

18) Tepas JJ 3rd, Ramenofsky ML, Mollitt DL, et al. The Pediatric Trauma Score as a predictor of injury severity: an objective assessment. J Trauma. 1988;28:425-9. DOI:10.1097/00005373-198804000-00001

19) Nair AB, Cohen MJ, Flori HR. Clinical Characteristics, Major Morbidity, and Mortality in Trauma-Related Pediatric Acute Respiratory Distress Syndrome. Pediatr Crit Care Med. 2020;21:122-8. DOI:10.1097/ PCC. 0000000000002175

20) Hildebrand F, van Griensven M, Garapati R, et al. Diagnostics and Scoring in Blunt Chest Trauma. Eur J Trauma. 2002;28:157-67. DOI: 10.1007/s00068-002-1192-1

21) Marts $B$, Durham $R$, Shapiro $M$, et al. Computed tomography in the diagnosis of blunt thoracic injury. Am J Surg. 1994;168:688-92. DOI:10.1016/s0002-9610(05)80146-1 